\begin{tabular}{|c|c|c|}
\hline BIODIK & $\begin{array}{l}\text { BIODIK: Jurnal IImiah Pendidikan Biologi } \\
\text { ISSN 2580-0922 (online), ISSN 2460-2612 (print) } \\
\text { Volume 07, Nomor 04, Tahun 2021, Hal. 18-28 } \\
\text { Available online at: } \\
\text { https://online-journal.unja.ac.id/biodik }\end{array}$ & BIODIK \\
\hline
\end{tabular}

Research Article

open access

\title{
Pengaruh Model Socio-Scientific Issue Terhadap Keterampilan Memecahkan Masalah Menggunakan Aplikasi Powtoon pada Materi Perubahan Lingkungan
}

\section{(Effect of Socio-Scientific Issue Model on Problem Solving Skills Using Powtoon Application on Environmental Change Materials)}

\author{
Elsa Hanifah*, Setiono, Gina Nuranti \\ Program Studi Pendidikan Biologi, \\ *Corresponding Author: elsa hanifah@ummi.ac.id
}

Fakultas Keguruan dan IImu Pendidikan, Universitas Muhammadiyah Sukabumi

JIn. R. Syamsudin, S.H. No. 50, Kec. Cikole, Kota Sukabumi, Jawa Barat 43113, Indonesia

\begin{tabular}{|c|c|}
\hline Informasi Artikel & ABSTRACT \\
\hline $\begin{array}{l}\text { Submit: } 04-07-2021 \\
\text { Diterima: } 20-11-2021 \\
\text { Dipublikasikan: } 13-12-2021\end{array}$ & $\begin{array}{l}\text { Problem solving skills are one of the needs of learners in facing the challenges } \\
\text { of the } 21 \text { st century. This study aims to determine the influence of socio-scientific } \\
\text { issue models on problem solving skills using powtoon applications. This type of } \\
\text { research is quasi experimental with } 2 \text { classes including control class and } \\
\text { experimentation. The subjects in this study were students of grade X MIPA } 3 \\
\text { consisting of } 8 \text { male student and } 23 \text { female student and X MIPA } 4 \text { consisting of } \\
7 \text { male student and } 25 \text { female student of SMAN } 3 \text { sukabumi city. The instrument } \\
\text { used in this study is a test of problem solving skills. The data of the two average } \\
\text { difference test results using the Wilcoxon test showed that the N-gain of the } \\
\text { experimental class with the control class differed significantly (sig=0.00 value). } \\
\text { This suggests the use of the SSI model of problem-solving skills in learners using } \\
\text { powtoon applications has an influence. This is because the SSI model provides } \\
\text { social issues or issues that are being faced by learners by providing authentic } \\
\text { problems that affect problem solving skills. Learners have a sense of tolerance } \\
\text { and critical. Achievement of learners' problem solving skills indicators excels in } \\
\text { identifying problems and identifying the cause of problems. Achievements are } \\
\text { being made on indicators of choosing solutions, implementing solutions and } \\
\text { evaluating them. Low on indicator identifies solution. The value of making a vidio } \\
\text { is directly proportional to the test score of problem solving skills. This SSI model } \\
\text { is suitable for use by medium groups. }\end{array}$ \\
\hline & Key words: socio-scientific issue model, problem solving skills, powtoon \\
\hline Penerbit & ABSTRAK \\
\hline $\begin{array}{l}\text { Program Studi Pendidikan Biologi } \\
\text { FKIP Universitas Jambi, } \\
\text { Jambi- Indonesia }\end{array}$ & $\begin{array}{l}\text { Keterampilan memecahkan masalah menjadi salah satu kebutuhan peserta } \\
\text { didik dalam menghadapi tantangan abad } 21 \text {. Penelitian ini bertujuan untuk } \\
\text { mengetahui pengaruh model socio-scientific issue terhadap keterampilan } \\
\text { memecahkan masalah menggunakan aplikasi powtoon. Jenis penelitian ini } \\
\text { merupakan quasi eksperimental dengan } 2 \text { kelas diantaranya kelas kontrol dan } \\
\text { eksperimen. Subjek dalam penelitian ini adalah peserta didik kelas X MIPA } 3 \\
\text { terdiri dari } 8 \text { siswa dan } 23 \text { siswi serta X MIPA } 4 \text { terdiri dari } 7 \text { orang siswa dan } 25 \\
\text { siswi SMAN } 3 \text { kota Sukabumi. Instrumen yang digunakan pada penelitian ini } \\
\text { adalah tes keterampilan memecahkan masalah. Data hasil uji perbedaan dua } \\
\text { rerata menggunakan uji Wilcoxon yang menunjukan bahwa } \mathrm{N} \text {-gain kelas } \\
\text { eksperimen dengan kelas kontrol beda signifikan (nilai sig }=0,00 \text { ). Hal ini }\end{array}$ \\
\hline
\end{tabular}


menunjukkan penggunaan model SSI terhadap keterampilan pemecahan masalah pada peserta didik menggunakan aplikasi powtoon memiliki pengaruh. Hal ini disebabkan karena model SSI memberikan isu sosial atau isu yang sedang dihadapi oleh peserta didik dengan memberikan permasalahan yang autentik yang berpengaruh terhadap keterampilan pemecahan masalah. Peserta didik memiliki rasa toleransi dan kritis. Pencapaian indikator keterampilan pemecahan masalah peserta didik unggul dalam mengidentifikasi masalah dan mengidentifikasi penyebab masalah. Pencapaian yang sedang pada indikator memilih solusi, implementasi solusi dan evaluasi. Rendah pada indikator mengidentifikasi solusi. Nilai pembuatan vidio berbanding lurus dengan nilai tes keterampilan pemecahan masalah. Model SSI ini cocok digunakan oleh kelompok sedang.

Kata kunci:Model socio-scientific issue, keterampilan memecahkan masalah, powtoon

This BIODIK : Jurnal IImiah Pendidikan Biologi is licensed under a CC BY-NC-SA (Creative Commons Attribution-ShareAlike 4.0 International License)

\section{PENDAHULUAN}

Undang-Undang nomor 20 tahun 2003 pasal 1 ayat (2) menjelaskan bahwa lembaga pendidikan harus tanggap dengan tuntutan zaman yang saat ini dihadapkan dengan kemampuan abad 21. Tantangan tersebut diantaranya berfikir inventif salah satunya adalah memecahkan masalah. Empat katagori abad 21 diantaranya cara berpikir, cara bekerja, alat untuk bekerja dan hidup di dunia (Redhana, 2019). Lembaga pendidikan menciptakan peserta didik yang siap menghadapi berbagai permasalahan di masa depan. Keterampilan pemecahan masalah menjadi salah satu kebutuhan peserta didik dalam menghadapi masa depan dan perkembangan zaman. Keterampilan pemecahan masalah membuat peserta didik mengembangkan keterampilan kritis, kreatif, kolaboratif dan komunikasi (Redhana, 2019). Pemecahan masalah merupakan inti dari pendidikan (Nayazik, 2017). Perkembangan dunia yang cepat baik dari bidang pendidikan, kesehatan, perekonomian bahkan digital membutuhkan adanya keterampilan memecahkan masalah.

Keterampilan memecahkan masalah sangat penting dan berguna bagi individu ketika menghadapi masalah, mencari solusi dan memilih solusi yang terbaik dengan mempertimbangkan kondisi. Keterampilan memecahkan masalah merupakan proses kognitif yang diaplikasikan dengan perilaku, outcome dan tindakan yang berdasarkan pengetahuan (Ahghar, 2012). Peserta didik menemukan hubungan antara pengetahuan dengan masalah, sehingga mereka akan merasakan manfaat belajar dan meningkatkan pengetahuan, keterampilan serta sikap (Suryawati et al., 2010). Keterampilan memecahkan masalah dan wawasan berpikir dapat membuat masa depan lebih baik dan dapat dilatihkan pada peserta didik (Rustaman, 2006). Keterampilan memecahkan masalah merupakan proses kognitif yang membutuhkan pedagogi untuk berkembang (Hassan et al., 2012).

Hasil penelitian sebelumnya bahwa keterampilan memecahkan masalah masih rendah dibawah 50\% ditingkat SMA (Setyadi et al., 2019). Fakta dilapangan dalam kegiatan PLP 1 bahwa keterampilan memecahkan masalah masih rendah dilihat dari hasil observasi peserta didik belum bisa mengidentifikasi masalah dan banyak yang menyelesaikan tugas tanpa memeriksa kembali. Salah satu faktor rendahnya keterampilan memecahkan masalah adalah motivasi. Pemecahan masalah yang terkait isu-isu permasalahan yang berada ditengah masyarakat atau yang peserta didik alami akan meningkatkan daya 
tarik untuk memecahkan masalah. Faktor pendukung lain dalam memecahkan masalah harus didukung dengan intelektual, moral dan etika.

Keterampilan pemecahan masalah merupakan kemampuan dasar terhadap permasalahan kehidupan (Ahghar, 2012). Keterampilan pemecahan masalah merupakan proses pembelajaran dan peningkatan yang berkelanjutan (Shettar et al., 2020). Keterampilan memecahkan masalah melatih peserta didik untuk mengetahui hubungan antara pengetahuan dengan masalah dan merasakan manfaat belajar (Suryawati et al., 2010). Kesiapan peserta didik yang terbiasa menghadapi permasalah dalam kegiatan pembelajaran mampu mempersiapkan mental anak dalam menghadapi persoalan dalam dunia nyata (Cahyani \& Setyawati, 2016). Indikator pemecahan masalah menurut Barkman \& Matchemes 2002 diantaranya identifikasi masalah, menganalisis kemungkinan penyebab, mengidentifikasi solusi, memilih solusi, mengimplementasikan solusi dan evaluasi. Adanya pandemik covid-19 meningkatkan kecemasan dan ketakutan berlebih yang dapat mempengaruhi keterampilan memecahkan masalah (Korkmaz et al., 2020). Work From Home (WFH) merupakan solusi yang diterapkan pemerintah saat pandemik covid-19 bekerja dari rumah dimana karyawan dan peserta didik melakukan pekerjaan, belajar dan mengajar dari rumah. Namun, kenyataannya masalah yang dihadapi masyarakat Indonesia yaitu pandemik covid-19 dan dampak diberlakukan WFH bagi lingkungan mengharuskan kita memiliki keterampilan pemecahan masalah agar permasalahan dapat terselesaikan.

Model Socio-Scientific Issue (SSI) berpotensi untuk melatih keterampilan memecahkan masalah pada pembelajaran peserta didik. Sintak model SSI meliputi orientasi isu, mengkaji materi, eksplorasi nilai etika, diskusi, kontruksi pernyataan, kajian etika, mengambil keputusan dan refleksi (Aisya et al., 2017). Model SSI merupakan model yang mengangkat isu atau permasalahan yang ada disekitar. SSI bertujuan menstimulasi perkembangan intelektual, moral dan etika serta kesadaran hubungan antara sains dengan kehidupan sosial (Zeidler et al., 2005). Permasalahan semakin banyak bermunculan mulai dari bidang pendidikan, ekonomi dan kesehatan seperti di awal tahun 2020. Indonesia menghadapi pandemik covid19 tak terkecuali peserta didik, tekanan psikologis yang luar biasa seperti rasa cemas, ketakutan dan depresi (Korkmaz et al., 2020). Permasalahan ini menuntut kita untuk memiliki keterampilan pemecahan masalah dalam menghadapi setiap permasalahan.

Model SSI bertujuan menstimulan intelektual, moral dan etika serta kesadaran hubungan antara sains dan sosial yang tidak dapat dipisahkan (Zeidler et al., 2005). Model SSI dapat menggali lebih dalam mengenai hakikat sains (Nuangchalerm, 2010). Dimana hakikat sains meliputi sikap ilmiah, proses ilmiah dan produk. Model SSI menggunakan masalah atau isu yang terdapat disekitar sosial yang berkaitan erat dengan sains secara konseptual (Anagün \& Özden, 2010). Pemilihan materi perubahan lingkungan ini sangat tepat digunakan dalam meningkatkan keterampilan memecahkan masalah menggunakan model SSI. Isu sosial yang digunakan adalah dampak dari WFH. Maka dapat disimpulkan bahwa model SSI merupakan rangkaian pembelajaran dengan isu sosial dan mencari solusi terhadap isu tersebut. Model SSI dapat digunakan dalam kegiatan pembelajaran daring dan dalam kondisi WFH.

Tahun 2020 Menteri pendidikan dan Kebudayaan Republik Indonesia terkait surat edaran Nomor 4 Tahun 2020 tentang pelaksanaan kebijakan pendidikan dalam masa darurat penyebaran corona virus disease (COVID-19). Indonesia memberlakukan PSBB untuk menekan penyebaran virus (Harnani, 2020). WFH menjadi pilihan pemerintah untuk memutuskan rantai penyebaran virus. Setelah diterapkannya WFH semua aktivitas baik karyawan, peserta didik, guru dan lain-lain dilakukan didalam rumah. Sistem pembelajaran menjadi daring dan guru harus memastikan kegiatan belajar mengajar tetap berjalan (Harnani, 2020). 
Penerapan WFH ini memiliki dampak positif dan negatif terutama terhadap lingkungan. Dampak positif WFH seperti kemacetan menjadi berkurang dan asap yang dihasilkan oleh kendaraan pun berkurang. Dampak negatif WFH dengan kegiatan masyarakat yang banyak dilakukan di dalam rumah meningkatkan pemakaian zoom, google meet, youtube dan neflix sehingga pemakaian baterai cepat habis yang mengakibatkan penggunaan listrik menjadi meningkat. Limbah yang dihasilkan pembangkit listrik yaitu gas Co2 (Harjanto, 2008). Radiasi sinar infra merah dari bumi akan kembali ke permukaan bumi karena tertahan oleh rumah kaca menyebabkan pemanasan global (Harjanto, 2008).

Permasalahan dari dampak WFH tidak hanya terkait penggunaan listrik. Limbah rumah tangga pun meningkat. Mayoritas warga belanja online meningkat (LIPI, 2020). Meningkatnya layanan delivery makanan online dan jumlah sampah plastik pembungkus paket meningkat (LIPI, 2020). Permasalahan tersebut mengharuskan kita berpikir untuk menghadapi dan mencari solusi situasi pandemik ini.

Era revolusi industri 4.0 dengan perkembangan digital yang sangat pesat dan harus dimanfaatkan sebaik mungkin, tidak terkecuali dalam bidang pendidikan. Penelitian ini melatih keterampilan pemecahan masalah peserta didik dengan memberikan solusi dari dampak WFH terhadap lingkungan dalam bentuk vidio melalui aplikasi powtoon yang memiliki banyak fitur agar lebih menarik dalam mengerjakan tugas. Powtoon merupakan sosial media pembelajaran audio visual (Ariyanto et al., 2018). Peserta didik mampu mengingat $20 \%$ dari yang dilihat, $30 \%$ yang di dengar dan mengingat $50 \%$ dari yang dilihat dan didengar (Arifah et al, 2018). Powtoon mampu mengatasi keterbatasan ruang, waktu dan daya indera (Ernalida et al., 2018). Tujuan penggunaan aplikasi powtoon dalam mengerjakan tugas mengenai solusi terhadap isu (dampak WFH) supaya bermanfaat bagi masayarakat tidak hanya untuk diri sendiri tetapi dapat membagikan solusi tersebut kepada masyarakat melalui sosial media seperti WhatsApp, instagram dan lain-lain.

Keterbaruan dari penelitian ini yaitu menggunakan model SSI dalam pembelajaran untuk mengetahui keterampilan pemecahan masalah serta menggunakan aplikasi powtoon sebagai media yang membantu peserta didik dalam menginformasikan gagasannya dalam memberikan solusi terhadap masalah lingkungan dampak dari WFH. Dengan demikian, setelah peserta didik belajar materi bab perubahan lingkungan menggunakan model SSI memiliki keterampilan pemecahan masalah.

\section{METODE PENELITIAN}

Jenis penelitian ini adalah quasi eksperimental karena pengambilan subjek secara tidak acak ke dalam kelas kontrol dan eksperimen. Teknik yang digunakan adalah purposive sampling karena kelas yang digunakan adalah kelas yang sudah ada X MIPA 3 dan X MIPA 4 pemilihan kedua kelas tersebut berdasarkan nilai dari kedua kelas ini tidak berbeda jauh. Penelitian ini dilakukan dari bulan Maret minggu ke-3 sampai bulan April minggu ke-1. Subjek penelitian peserta didik SMAN 3 Kota Sukabumi kelas $X$ MIPA 4 terdiri dari 7 orang siswa dan 25 siswi sebagai kelas eksperimen dan X MIPA 3 sebagai kelas kontrol yang terdiri dari 8 siswa dan 23 siswi. Terdapat dua variabel yang digunakan pada penelitian ini diantaranya keterampilan memecahkan masalah sebagai variabel terikat dan model SSI sebagai variabel bebas. Kegiatan pembelajaran menggunakan model SSI dikelas eksperimen dan penggunaan model inquiry dikelas kontrol. Tujuan penelitian untuk mengetahui pengaruh model SSI dan model inquiry terhadap keterampilan memecahkan masalah.

Instrumen yang digunakan adalah tes keterampilan memecahkan masalah. Tujuannya untuk mengetahui keterampilan pemecahan masalah peserta didik. Indikator keterampilan pemecahan masalah yang digunakan dari Barkman \& Matchemes 2002 diantaranya identifikasi masalah, menganalisis kemungkinan penyebab, mengidentifikasi solusi, memilih solusi, mengimplementasikan solusi dan 
evaluasi. Penelitian ini melalui tahapan judgement dari para ahli dan uji validitas, reabilitas, kesukaran serta daya pembeda menggunakan sofware anates 4.0.9. Data yang diperoleh diolah menggunakan program SPSS. Soal terdiri dari 15 butir yang telah disesuaikan dengan indikator keterampilan pemecahan masalah.

Data diambil dari hasil pretes dan posttest untuk mengetahui keterampilan pemecahan masalah peserta didik pada bab keseimbangan lingkungan mengenai isu WFH. Penelitian ini menggunakan metode non parametrik uji Wilcoxon. Peserta didik dikelompokan menjadi 3 katagori berdasarkan nilai dari tes yang diberikan katagori tersebut dintaranya tinggi, sedang dan rendah. Tujuannya untuk mengetahui model SSI cocok dikelas tinggi, sedang atau rendah. Kegiatan pembelajaran dilakukan secara daring menggunakan beberapa platform seperti google classroom untuk mengisi kehadiran dan pengumpulan tugas, whatsApp group dan google meet digunakan untuk penyampaian materi dan diskusi, baik dikelas kontrol maupun eksperimen. Media yang digunakan sama antara kelas control dan eksperimen perbedaan kedua kelas hanya terdapat pada penggunaan model saja. Alur pembelajaran sesuai dengan RPP yang telah dibuat terdapat apersepsi, inti dan penutup hanya terdapat perbedaan antara RPP daring dan luring. Perbedaannya RPP daring kehadiran dilakukan secara online, penyampaian materi dengan google meet dan dilanjut dengan diskusi menggunakan whatsApp group serta pengumpulan tugas diserahkan melalui google classroom. Tugas berupa vidio yang dibuat menggunakan aplikasi powtoon vidio menjadi lebih interaktif dan menarik tugas di upload dan linknya diserahkan melalui google classroom. Vidio memuat permasalahan atau isu terkini, penjelasan dalam bentuk suara yang mudah dipahami, penjelasan dalam bentuk tulisan. Gambar atau desain yang menarik dan solusi yang diberikan terhadap isu tersebut. Materi yang digunakan adalah bab perubahan lingkungan.

\section{HASIL PENELITIAN DAN PEMBAHASAN}

Penelitian ini menggunakan uji non parametik karena data beda signifikan saat uji normalitas. Uji non parametrik menggunakan wilcoxon signed ranks test (Maryadi, 2020). The wilcoxon signed ranks test merupakan statistik non parametik yang digunakan untuk membandingkan 2 sampel (Maryadi, 2020). Tabel 1 menyajikan N-gain uji Wilcoxon.

Tabel 1. N-gain uji Wilcoxon

\begin{tabular}{|c|c|c|c|c|}
\hline & & $\mathrm{N}$ & Mean Rank & Sum of Ranks \\
\hline \multirow[t]{4}{*}{$\begin{array}{l}\mathrm{N} \text {-gain kontrol - } \\
\mathrm{N} \text {-gain ekperimen }\end{array}$} & $\begin{array}{l}\text { Negative } \\
\text { Ranks }\end{array}$ & $25^{a}$ & 15.46 & 386.50 \\
\hline & $\begin{array}{l}\text { Positive } \\
\text { Ranks }\end{array}$ & $4^{\mathrm{b}}$ & 12.13 & 48.50 \\
\hline & Ties & $2^{c}$ & & \\
\hline & Total & 31 & & \\
\hline & \multicolumn{4}{|c|}{ Ngain kontrol - Ngain eksperimen } \\
\hline Z & \multicolumn{4}{|c|}{$-3,665^{b}$} \\
\hline Asymp. Sig. (2-tailed) & \multicolumn{4}{|c|}{0,000} \\
\hline
\end{tabular}

Berdasarkan tabel tersebut nilai $(\mathrm{Sig}=0,000)<0,005$. Artinya $\mathrm{H} 0$ ditolak dan $\mathrm{H} 1$ diterima. Hal ini menunjukan bahwa model SSI yang menyajikan isu sosial atau isu yang sedang dihadapi oleh peserta didik dengan memberikan permasalahan yang autentik memberikan pengaruh terhadap keterampilan pemecahan masalah peserta didik. Penggunaan model SSI dalam proses pembelajaran melatihkan 
peserta didik untuk memecahkan masalah lingkungan akibat dampak WFH. SSI memberikan kesempatan kepada peserta didik berhadapan dengan situasi konflik yang menyangkut sains dan kehidupan sosial (Dawson \& Venville, 2010).

Tabel 2. Kelompok tinggi, sedang dan rendah sebelum dilaksanakan percobaan

\begin{tabular}{cccc}
\hline \multirow{2}{*}{ No } & Kelompok & \multicolumn{2}{c}{ Jumlah Peserta Didik } \\
\cline { 3 - 4 } & & Eksperimen & Kontrol \\
\hline Tinggi & 3 & 2 \\
\hline Sedang & 19 & 20 \\
\hline Rendah & 9 & 10 \\
\hline
\end{tabular}

Data yang diperoleh sebelum percobaan pada kegiatan pembelajaran bab ekosistem, kelas eksperimen memiliki kelompok tinggi 3 orang, sedang 25 orang dan rendah 9 orang. Sedangkan kontrol memiliki kelompok tinggi 2, sedang 20 dan rendah 10 orang. Pengambilan data dari kelas yang sama MIPA 3 dan MIPA 4 terjadi perubahan dari data pada bab ekositem dan bab perubahan lingkungan saat penelitian.

Tabel 3. Kelompok tinggi, sedang dan rendah percobaan

\begin{tabular}{|c|c|c|c|c|c|}
\hline \multirow[t]{2}{*}{ No } & \multirow[t]{2}{*}{ Kelompok } & \multicolumn{2}{|c|}{ Jumlah Peserta Didik } & \multicolumn{2}{|c|}{ Rata-rata N-Gain } \\
\hline & & Eksperimen & Kontrol & Eksperimen & Kontrol \\
\hline 1 & $g>0,7$ (Tinggi) & 6 & 2 & 0,62 (sedang) & 0,26 (rendah) \\
\hline 2 & $0,3<\mathrm{g}<0,7$ (Sedang) & 24 & 21 & & \\
\hline 3 & $\mathrm{~g}<0,3$ (Rendah) & 2 & 8 & & \\
\hline
\end{tabular}

Berdasarkan data yang diperoleh pada bab perubahan lingkungan bahwa kelas eksperimen memiliki kelompok tinggi jika $\mathrm{g}>0,7$ sebanyak 6 orang, kelompok jika $0,3<\mathrm{g}<0,7$ peserta didik yang masuk kelompok sedang berjumlah 24 orang serta dapat dikelompokkan rendah jika $g<0,3$ dengan jumlah 2 orang. Rata-rata N-gain 0,62 masuk kedalam kataegori sedang. Kelas kontrol kelompok tinggi 2 orang, sedang 14 orang dan rendah 15 orang dengan $\mathrm{N}$-gain 0,26 dengan kategori rendah. Dilihat dari data bab ekosistem dan pada penelitian terjadi peningkatan kelompok tinggi dan sedang di kedua kelas dan penurunan di kelompok rendah.

Perubahan dan peningkatan kemampuan peserta didik dapat dirasakan, dilihat dari tabel 2 dan 3 pengelompokan tinggi, sedang, rendah dikelas eksperimen. Diantaranya kelompok tinggi yang asalnya hanya 3 orang menjadi 6 orang, kelompok sedang dari 19 menjadi 24 orang serta penurunan kelompok rendah yang asalnya 9 menjadi 2 orang. Model SSI ini cocok digunakan dikelompok sedang. Berdasarkan rata-rata nilai dari selisih antara pretes dan posttest.

Menguji keterampilan memecahkan masalah menggunakan tes pilihan ganda yang diberikan kepada peserta didik berjumlah 15 butir soal sesuai dengan indikator keterampilan memecahkan masalah diantaranya identifikasi masalah (I1), menganalisis kemungkinan penyebab (I2), mengidentifikasi solusi (I3), memilih solusi (I4), mengimplementasikan solusi (I5) dan evaluasi (I6). Indikator ke 1 sampai 3 masing-masing terdiri atas 3 butir soal dan indikator 4 sampai 6 masing-masing terdiri dari 2 butir soal. Hasil pencapaian peserta didik terhadap indikator keterampilan memecahkan masalah dapat dilihat pada gambar 1 dan gambar 2 . 


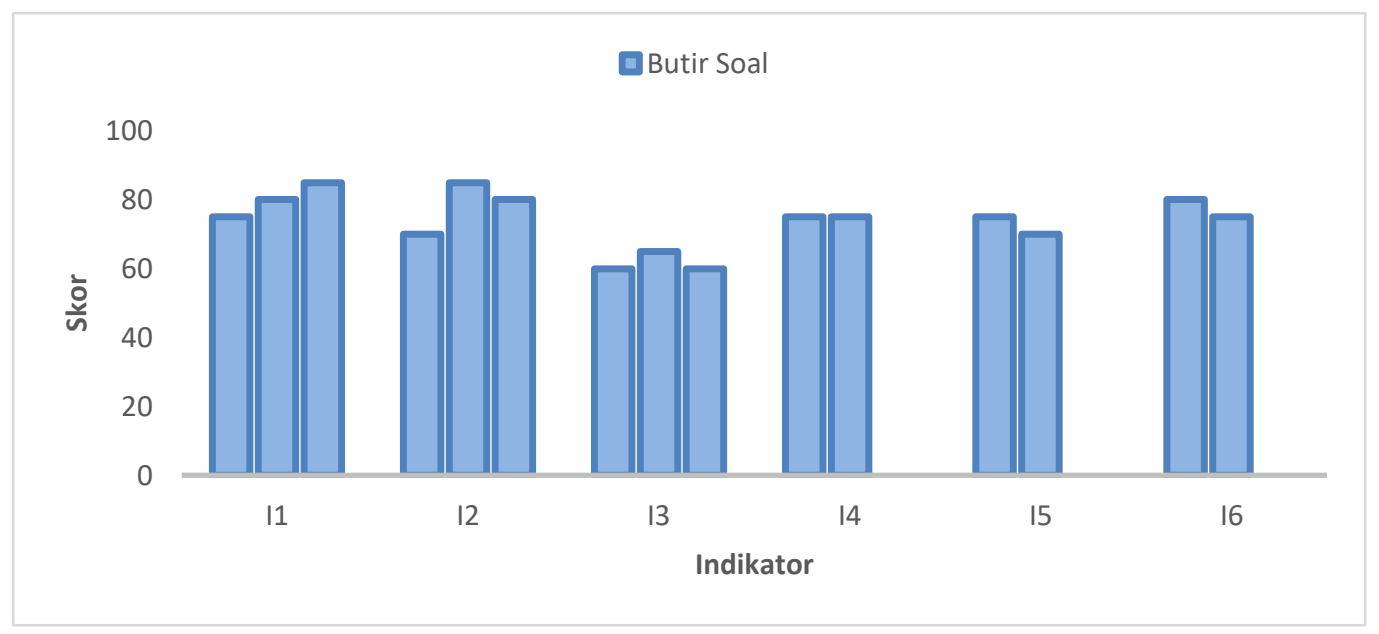

Gambar 1. Pencapaiaan peserta didik terhadap indikator keterampilan memecahkan masalah kelas eksperimen

Gambar 1 merupakan gambaran pencapaian peserta didik terhadap indicator keterampilan memecahkan masalah pada kelas eksperimen. Kelas eksperimen adalah kelas yang diberi perlakuan dengan menggunakan model socio-scientific issue (SSI).

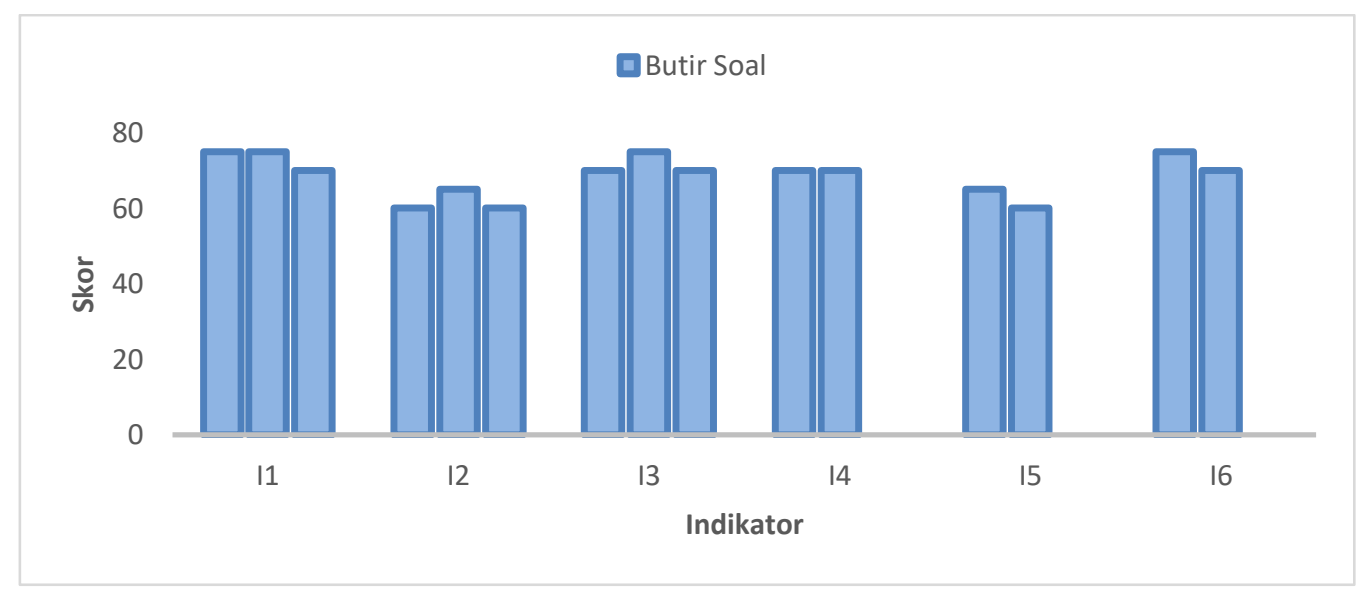

Gambar 2. Pencapaiaan peserta didik terhadap indikator keterampilan memecahkan masalah kelas kontrol

Berdasarkan data diatas pencapaian indikator keterampilan memecahkan masalah dikelas kontrol dan eksperimen memiliki perbedaan. Kelas eksperimen unggul terhadap indikator menganalisis masalah terkait dampak WFH dan menganalisis penyebab (pencemaran udara dan air) dengan rata-rata nilai 75-85. Pencapaian sedang pada indikator memilih solusi, implementasi dan evaluasi dengan ratarata nilai 70-75. Namun, rendah pada indikator mengidentifikasi solusi dngan rata-rata nilai 65-70. Sedangkan pada kelas kontrol mengidentifikasi masalah nilainya yang paling unggul dengan rata-rata nilai 75-80. Pencapaian sedang pada indikator mengidentifikasi solusi, memilih solusi dan evaluasi dengan rata-rata nilai 70-75 dan yang paling rendah indikator mengidentifikasi penyebab dan mengimplementasikan solusi dengan rata-rata nilai 60-65. Berdasarkan penjelasan tersebut artinya pencapaian yang unggul indikator keterampilan pemecahan masalah peserta didik sudah mulai 
menguasai indikator tersebut, sebaliknya indikator yang pencapaiannya paling rendah harus dilatihkan kembali kepada peserta didik.

Pencapaian indikator pada kelas eksperimen lebih unggul dari kelas kontrol. Artinya pembelajaran yang menggunakan isu sosial berdampak positif kepada peserta didik terhadap keterampilan pemecahan masalah. Melatih peserta didik dengan isu yang dihadapi dalam kegiatan pembelajaran akan membiasakan peserta didik dalam memecahkan masalah, karena keterampilan pemecahan masalah tidak dimiliki sejak lahir, namun diperoleh dari proses belajar dan latihan.

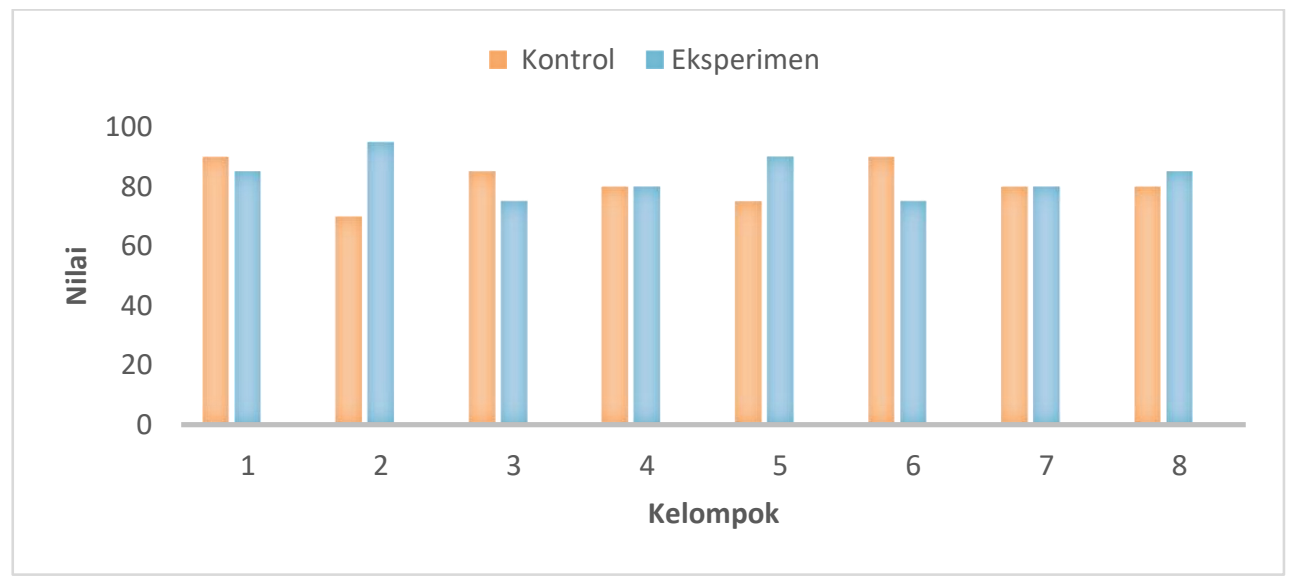

Gambar 3. Nilai tugas video

Berdasarkan data yang diperoleh pada kelas kontrol nilai rata-rata yang diperoleh 81 dan nilai rata-rata kelas eksperimen 83 . Setiap kelas dibagi menjadi 8 kelompok dengan pembagian anggota kelompok secara acak yang kemudian nama-nama anggota setiap kelompok dibagikan melalui whatsApp group. Penilaian pembuatan vidio bermacam-macam. Kelas kontrol memiliki nilai minimum 70 diperoleh kelompok 2 dan nilai maksimum 90 diperoleh kelompok 1 dan 6 . Kelas eksperimen memiliki nilai minimum 75 dipeloh kelompok 3 dan 7 sedangkan nilai maksimum dikelas eksperimen 95 diperoleh kelompok 2 . Penilaian vidio yaitu memuat permasalahan atau isu terkini, penjelasan dalam bentuk suara yang mudah dipahami, penjelasan dalam bentuk tulisan. gambar atau desain yang menarik mengenai penyebab dan dampak serta solusi yang diberikan terhadap isu tersebut.

Berdasarkan data tabel dan gambar ditemukan bahwa peserta didik yang memiliki nilai tinggi pada pembuatan vidio mengenai pemecahan permasalahan yaitu peserta didik yang nilainya tinggi dalam mengisi soal tes pilihan ganda tes keterampilan pemecahan masalah. Artinya nilai tugas vidio berbanding lurus dengan nilai tes keterampilan pemecahan masalah.

Kegiatan pembelajaran dikelas eksperimen menggunakan model SSI. Pembelajaran diawali dengan pengangkatan isu terkini yang diambil dari berita di media sosial, terkait dampak WFH bagi lingkungan. Peserta didik melakukan kegiatan menganalisis apa yang menjadi penyebab permasalahan, dampak, solusi, solusi yang terbaik dan evaluasi. Isu yang autentik yang dirasakan oleh peserta didik menjadi lebih menarik dan meningkatkan ke ingin tahuan peserta didik dalam kegiatan pembelajaran. Peserta didik mengetahui pengetahuan awal yang mereka tahu tentang WFH dan yang mereka rasakan saat diberlakukan WFH. Sedangkan dikelas kontrol peserta didik melakukan kegiatan mencari tahu apakah warna lumut kerak yang ada disekitar rumah masing-masing. Kemudian dihubungkan dengan tercemar atau tidaknya udara. 
Tugas yang diberikan kepada peserta didik membuat vidio memuat permasalahan yang diangkat dari berita dan media sosial mengenai peningkatan penggunaan listrik selama WFH, meningkatnya belanja online dan peningkatan sampah rumah tangga saat diberlakukannya WFH yang dihubungkan dengan dampak bagi lingkungan. Isi vidio mengenai pengangkatan isu, penyebab, dampak dan solusi yang terbaik tentang isu tersebut. Pembuatan vidio menggunakan aplikasi powtoon yang memiliki fitur menarik dan tugas di upload melalui youtube. Tujuannya agar bisa bermanfaat untuk peserta didik dan masyarakat untuk lebih memperhatikan lingkungan.

Peserta didik mulai berpikir kritis dan memiliki rasa toleransi yang tinggi terhadap masalah lingkungan dan masyarakat yang menjadi salah satu sikap ilmiah, peserta didik dapat memecahkan masalah dengan cara identifikasi masalah, menganalisis penyebab, dampak, mengidentifikasi solusi, memilih solusi yang terbaik. Membuat vidio mengenai solusi atas dampak WFH terhadap lingkungan menggunakan aplikasi powtoon. Pembuatan vidio menggunakan aplikasi powtoon membuat peserta didik lebih semangat dalam mengerjakan tugas, karena terdapat fitur-fitur yang berbeda dengan aplikasi pada umumnya. Powtoon meningkatkan motivasi peserta didik dalam proses pembelajaran (Nurdiansyah et al., 2018). Penggunaan aplikasi powtoon untuk meningkatkan minat dan hasil belajar siswa (Ariyanto et al., 2018).

Meskipun vidio yang dihasilkan peserta didik menggunakan aplikasi powtoon lebih menarik. Namun, terdapat kendala saat peserta didik menggunakan aplikasi powtoon mulai dari banyaknya fitur karena aplikasi ini baru peserta didik kenal, kuota, sinyal dan tidak memiliki leptop. Guru dan peserta didik dalam kegiatan pembelajaran daring menggunakan jaringan internet (Harnani, 2020). Aplikasi powtoon memang berbasis online yang membutuhkan kuota dan sinyal yang cukup dan penggunaan powtoon melalui handphone sedikit susah dibandingkan melalui leptop.

Keterampilan pemecahan masalah yang dilatihkan kepada peserta didik mengakibatkan peserta didik menyelesaikan masalah secara logis dan sistematis. Keterampilan pemecahan masalah membantu peserta didik mengambil keputusan secara tepat, cermat, sistematis, logis dan dapat mempertimbangkan dari berbagai sudut pandang (Paidi, 2010). Keterampilan pemecahan masalah dan wawasan berpikir dapat membuat masa depan lebih baik dan dapat dilatihkan pada peserta didik (Rustaman, 2006). Penggunaan model SSI dalam kegiatan pembelajaran memiliki pengaruh terhadap keterampilan pemecahan masalah. Selain itu peserta didik memiliki rasa toleransi terhadap lingkungan dan masyarakat serta berpikir kritis. Model SSI melatih peserta didik terhadap sikap ilmiah, proses dan produk. SSI dapat menggali lebih dalam mengenai hakikat sains (Nuangchalerm, 2010). Penggunaan model SSI pada pembelajaran membekalkan keterampilan memecahkan masalah. Peserta didik menemukan hubungan antara pengetahuan dengan masalah, sehingga mereka akan merasakan manfaat belajar dan meningkatkan pengetahuan, keterampilan serta sikap (Suryawati et al., 2010). Dengan demikian, penggunaan model SSI dapat meningkatkan keterampilan pemecahan masalah peserta didik.

\section{SIMPULAN}

Penggunaan model SSI berpengaruh terhadap keterampilan pemecahan masalah menggunakan aplikasi powtoon. Keterampilan pemecahan masalah menjadi bekal peserta didik dalam menghadapi permasalahan dan masa depan. Hasil data penelitian yang didapatkan dalam menggunakan model SSI diantaranya melatih keterampilan pemecahan masalah, isu yang autentik yang sedang dihadapi peserta didik meningkatkan keingin tahuan peserta didik dalam belajar, memiliki rasa toleransi terhadap 
lingkungan dan masyarakat, memiliki pemikiran yang kritis dalam menyelesaikan permasalahan, pencapaian indikator keterampilan pemecahan masalah peserta didik unggul dalam mengidentifikasi masalah dan mengidentifikasi penyebab masalah. Pencapaian yang sedang pada indikator memilih solusi, implementasi solusi dan evaluasi. Rendah pada indikator mengidentifikasi solusi serta peserta didik yang nilai penugasan vidionya tinggi adalah peserta didik yang nilainya tinggi dalam mengisi soal. Model SSI cocok digunakan untuk kelompok sedang.

\section{UCAPAN TERIMAKASIH}

Segala puji dan syukur untuk Allah SWT. Terimakasih kepada dosen pembimbing, orangtua, kepada kepala sekolah dan guru biologi SMAN 3 KOTA SUKABUMI. Serta ucapan terima kasih kepada semua pihak yang telah mendukung penelitian ini.

\section{RUJUKAN}

Ahghar, G. (2012). Effect of Problem-solving Skills Education on Auto-Regulation Learning of High School Students in Tehran. Procedia - Social and Behavioral Sciences, 69, 688-694. https://doi.org/10.1016/j.sbspro.2012.11.462

Aisya, N., Wibowo, Y., \& Aminatun, T. (2017). The Influence Of Socio-Scientific Issues On Reflective Judgment Of High School's Student In Ecosystem Material. Jurnal Bioedukatika, 4(2), 14. https://doi.org/10.26555/bioedukatika.v4i2.5346

Anagün, Ş. S., \& Özden, M. (2010). Teacher candidate's perceptions regarding socio-scientific issues and their competencies in using socio-scientific issues in science and technology instruction. Procedia - Social and Behavioral Sciences, 9, 981-985. https://doi.org/10.1016/j.sbspro.2010.12.271

Arifah Umi, H.Suyitno, N. R. Dewi. (2018). Meningkatkan Kemampuan Berpikir Kritis Matematis Melalui Model Brain Based Learning Berbantuan Powtoon. Prosiding Seminar Nasional Matematika. https://journal.unnes.ac.id/sju/index.php/prisma/article/view/29258/12895

Ariyanto, R., Kantun, S., \& Sukidin, S. (2018). Penggunaan Media Powtoon Untuk Meningkatkan Minat Dan Hasil Belajar Siswa Pada Kompetensi Dasar Mendeskripsikan Pelaku-Pelaku Ekonomi Dalam Sistem Perekonomian Indonesia. JURNAL PENDIDIKAN EKONOMI: Jurnal IImiah IImu Pendidikan, IImu Ekonomi Dan Ilmu Sosial, 12(1), 122. https://doi.org/10.19184/jpe.v12i1.7622

Cahyani, H., \& Setyawati, R. W. (2016). Pentingnya Peningkatan Kemampuan Pemecahan Masalah melalui PBL untuk Mempersiapkan Generasi Unggul Menghadapi MEA. 151-160.

Ernalida, Yenni Liyawati, Ansorm Abdu Gafur, Nurul Hikmah, R. U. (2018). Powtoon: Media Pembelajaran Berbasis Teknologi Informasi Sebagai Upaya dalam Menciptakan Pembelajaran yang Menarik dan Kreatif. 132-137.

Harjanto, N. T. (2008). DAMPAK LINGKUNGAN PUSAT LISTRIK TENAGA FOSIL DAN PROSPEK PLTN SEBAGAI SUMBER ENERGI LISTRIK NASIONAL. Nur Tri Harjanto. Pusat Teknologi Bahan Bakar Nuklir.

Harnani, S. (2020). EFEKTIVITAS PEMBELAJARAN DARING DI MASA PANDEMI COVID-19. 2020-0707. https://bdkjakarta.kemenag.go.id/berita/efektivitas-pembelajaran-daring-di-masa-pandemicovid-19

Hassan, S. A. H. S., Yusof, K. M., Mohammad, S., Abu, M. S., \& Tasir, Z. (2012). Methods to Study Enhancement of Problem Solving Skills in Engineering Students Through Cooperative ProblemBased Learning. Procedia - Social and Behavioral Sciences, 56, 737-746. https://doi.org/10.1016/j.sbspro.2012.09.711

Korkmaz, S., Kazgan, A., Çekiç, S., Tartar, A. S., Balcı, H. N., \& Atmaca, M. (2020). The anxiety levels, quality of sleep and life and problem-solving skills in healthcare workers employed in COVID-19 services. Journal of Clinical Neuroscience, 80, 131-136. https://doi.org/10.1016/j.jocn.2020.07.073

LIPI. (2020). Peningkatan Sampah Plastik dari Belanja Online dan Delivery Selama PSBB | Lembaga 
IImu Pengetahuan Indonesia. 2020-05-23. http://lipi.go.id/berita/single/Peningkatan-SampahPlastik-dari-Belanja-Online-dan-Delivery-Selama-PSBB/22037

Maryadi. (2020). Membandingkan Hasil Uji Statistika Parametrik dan Nonparametrik ( Studi Kasus : Pelaksanaan Kebijakan Pengendalian Dana Idle Pemerintah Daerah ). Jurnal Of Applied Managerial Accounting, 4(1), 142-149.

Nayazik, A. (2017). Pembentukan Keterampilan Pemecahan Masalah Melalui Model IDEAL Problem Solving Dengan Teori Pemrosesan Informasi. Kreano, Jurnal Matematika Kreatif-Inovatif, 8(2), 182 190. https://doi.org/10.15294/kreano.v8i2.7163

Nuangchalerm, P. (2010). Engaging students to perceive nature of science through socioscientific issuesbased instruction. European Journal of Social Sciences, 13(1), 34-37.

Nurdiansyah, E., Faisal, E. El, \& Sulkipani, S. (2018). Pengembangan media pembelajaran berbasis PowToon pada perkuliahan Pendidikan Kewarganegaraan. Jurnal Civics: Media Kajian Kewarganegaraan, 15(1), 1-8. https://doi.org/10.21831/jc.v15i1.16875

Nuryani Rustaman. (2006). Literasi Sains Anak Indonesia 2000 \& 2003. Makalah Pada Seminar Sehari Hasil Studi Internasional Prestasi Siswa Indonesia.

Paidi. (2010). Model Pemecahan Masalah dalam Pembelajaran Biologi di SMA.

Redhana, I. W. (2019). Mengembangkan Keterampilan Abad Ke-21 Dalam Pembelajaran Kimia. Jurnal Inovasi Pendidikan Kimia, 13(1).

Setyadi, T. Y., Mardiyana, \& Triyanto. (2019). Mathematical problem solving skills using IDEAL model based on personality type. AIP Conference Proceedings, 2194(December). https://doi.org/10.1063/1.5139847

Shettar, A., Vijaylakshmi, M., \& Tewari, P. (2020). Categorizing student as a convergent and divergent thinker in problem-solving using learning analytics framework. Procedia Computer Science, 172(2019), 803-810. https://doi.org/10.1016/j.procs.2020.05.001

Suryawati, E., Osman, K., \& Meerah, T. S. M. (2010). The effectiveness of RANGKA contextual teaching and learning on student's problem solving skills and scientific attitude. Procedia - Social and Behavioral Sciences, 9, 1717-1721. https://doi.org/10.1016/j.sbspro.2010.12.389

Vaille Maree Dawson, G. V. (2010). Teaching Strategies for Developing Students' Argumentation Skills About Socioscientific Issues in High School Genetics. Res Sci Educ, 40, 133-148. https://doi.org/10.1007/s11165-008-9104-y

Zeidler, D. L., Sadler, T. D., Simmons, M. L., \& Howes, E. V. (2005). Beyond STS: A research-based framework for socioscientific issues education. Science Education, 89(3), 357-377. https://doi.org/10.1002/sce.20048 